KONSTRUKTIVISME, Vol. 7, No. 2, Juli 2015

p-ISSN: 1979-9438, e-ISSN: 2445-2355

FKIP Universitas Islam Balitar, Blitar

Web: konstruktivisme.unisbablitar.ejournal.web.id

\title{
KURIKULUM PENDIDIKAN ANAK USIA DINI
}

\author{
Imroatul Hasanah \\ Universitas Islam Balitar \\ JI. Majapahit 12A Blitar \\ Email: imroatulhasna@gmail.com
}

\begin{abstract}
This article reviews philosophy of early stage children in perspectives of theory, beneficial, and law enforcement in education context of in Indonesian government policy. Theoretically, early childhood is a golden era where children get benefits for the development of psychomotor and cognitive performance. This way, multiple intelligences are crucial potential teachers and parents should develop. The higher development early children would achieve is potential literacy where critical thinking, characters, and capacity building would be relied upon. Government policy devoted to this context should inditace strong policy, such as curriculum for children and law enforcement ensuring children to receive their rights and protection.
\end{abstract}

Keywords: children, golden age, law enforcement, potential.

\begin{abstract}
Abstrak
Makalah ini mengkaji mengenai filosofi anak usia dini dalam perspektif teori, keunggulan dan penerapan hukum dalam kontek pendidikan menurut kebijakan pemerintah Indonesia. Secara teori, anak usia dini memiliki usia emas untuk mengembangkan diri secara psikomotor dan kognitif. Untuk itu, pengembangan konsep intelegensia ganda yang dimiliki anak harus menjadi perhatian utama para guru dan orang tua. Pada taraf perkembangan lebih lanjut, potensi literasi yang meliputi perpikir kritis, karakter, dan pengembangan potensi diri harus diperhatikan. Peraturan pemerintah yang didedikasikan untuk pegembangan anak harus menunjukkan komitmen kuat misalnya dalam bentuk kurikulum anak dan penerapan kebijakan untuk perlindungan dan pemberian hak-hak anak.
\end{abstract}

Kata Kunci: kurikulum, pendidikan, dan anak usia dini

Pendidikan itu sudah dimulai dari anak sedini mungkin, bahkan ketika di dalam perut pun anak sudah bias mendengarkan suara di luar rahim, menurut penelitian yang telah berkembang ketika janin yang masih dalam kandungan setelah berumur 4 minggu dengan di putarkan lagu-lagu klasik maka akan membentuk karakter emosi anak. Oleh karena itu pendidikan anak usia dini dapat dilakukan sejak anak mulai belajar bicara 
dan mulai melihat serta mendengarkan kejadian-kejadian lingkungan sekitar, sekitar usia 3 tahun. Maka pada usia ini pendidikan harus mulai diperhatikan agar dapat mempengaruhi pola hidup anak ketika dewasa nanti, karena anak akan sangat teringat begitu kuat akan kejadian apapun yang dianggap anak penting dan tidak terlupakan sampai dewasa. Dan atas dasar inilah pemerintah mulai memikirkan akan betapa pentingnya pendidikan anak usia dini sebagai upaya menangkal tindak-tindak kriminal yang terjadi pada anak usia produktif.

Berlatar belakang dari hal ini pemerintah tergugah, khususnya departemen pendidikan nasional untuk membentuk sebuah direktorat baru yang bernama Direktorat Pendidikan Anak Dini Usia (PADU). Yaitu sebuah direktorat yang berada dibawah Direktorat Jenderal Pendidikan Luar Sekolah dan Pemuda, hal ini diharapkan dapat mendorong dan memfasilitasi masyarakat dibidang layanan pendidikan anak usia dini.

Manusia hidup akan selalu belajar dari semua yang ada dalam lingkungannya, tak lepas dari aspek terkecil sekalipun. Sejak dalam kandungan, manusia telah diciptakan untuk memulai belajar. Dari sini kita bisa mengetahui bahwa perlunya pendidikan itu mulai anak sejak usia dini. Bahkan usia anak pad ataman kanak-kanak sudah bisa dikatakan terlambat, menurut hasil penelitian dibidang neurologi yaitu Bloom, pada usia empat tahun pertama separuh kecerdasan manusia sudah terbentuk. Dalam arti pada usia tersebut otak anak tidak mendapatkan rangsangan yang maksimal, maka potensi otak anak tidak akan berkembang secara optimal. Secara keseluruhan sampai usia 9 tahun $80 \%$ kapasitas kecerdasan anak hanya bertabah sekitar $30 \%$ setelah usia 4 tahun hingga mencapai usia 8 tahun. Baru kemudian kapasitas kecerdsan anak bisa mencapai $100 \%$ setelah berusia sekitar 18 tahun.

Seiring perkembangan anak maka lebih baik pula jika terus diadakan pendampingan dan bimbingan terhadap perkembangannya. Karena jika tanpa adanya pendampingan dalam perkembangannya, maka akan sangat mempengaruhi pola piker dan tingkah lakunya ketika menuju dewasa. Dalam kenyataan sehari-hari sering kita jumpai anak-anak melakuakan tindakan criminal, hal ini yang membuat resah orang tua, dikarenakan seiring perkembangan dan kemajuan teknologi informasi.Hal ini banyak berpengaruh pada pola dan tingkah laku dala perkembangan anak menuju dewasa. Berlatar belakang dari hal ini pemerintah tergugah, khususnya departemen pendidikan nasional untuk membentuk sebuah direktorat baru yang bernama PADU. Yaitu sebuah direktorat yang berada dibawah Direktorat Jenderal Pendidikan Luar Sekolah dan Pemuda, hal ini diharapkan dapat mendorong dan memfasilitasi masyarakat dibidang layanan pendidikan anak usia dini.

Dari hal ini telah dibukanya lembaga-lembaga yang memfasilitasi anak usia dini untuk mendapatkan permainan yang layak dan mendidik serta mengebangkan tingkat kecerdasan anak. Seperti playgroup dan lain sebagainya.

\section{MASA ANAK USIA DINI}


Bisa dikatakan anak usia dini, disisni kita bisa melihat pada lingkungan sekitar kita. Sebetulnya ketika anak sudah bisa mendengarkan sesuatu hal, maka sesungguhnya anak tersebut sudah siap untuk mendapatkan pendidikan. Tetapi dalam hal ini dikategorikan anak usia dini yaitu ketika anak sudah bisa memulai bicara dan memulai menirukan halhal yang ada disekitarnya, maka selayaknya anak kita bombing dengan memberikan pendidikan yang patut, sesuai dengan usianya. Anak-anak usia dini biasanya sekitar usia 3-6 tahun, karena pada usia ini anak sangat antusias sekali dalam bermain dan menirukan perkataan serta tingkah laku dilingkungan sekitarnya.

Pada dasarnya diusia dini naka asih sangat sederhana dala pengenalan lingkungannya, tetapi juga bisa menjadi berbahaya karena pada masa ini anak sangat suka menirukan apa saja yang sudah dia lihat. Pada asa pra sekolah ini merupakan fase perkembangan individu, ketika anak mulai memiliki kesadaran tentang dirinya sebagai pria atau wanita, mulai dapat mengatur diri dalam buang air dan mengenal beberapa hal yang dianggap berbahaya, akan tetapi baru mengenal saja belum bisa mengendalikannya secara penuh.

Pada fase ini, anak lebih banyak bermain, karena dengan bermain berfungsi yang mempunyai pengaruh besar sekali pada perkebangannya.Jika pada orang dewasa sebagian besar dari perbuatannya diarahkan pada pencapaina tujuan dan prestasi dalam bentuk kegiatan kerja, maka kegiatan anak sebagian besar berbentuk aktivitas bermain (Yusuf, 2005:153).

Permainan pada masa anak merupakan kesibukan yang dipilih sendiri oleh tujuan.Kegiatan bermain seperti menyentak-nyentakkan tangan dan kakinya dengan tidak henti-hentinya, meremas-remas jari, dan menggoyang-goyangkan kakinya.Kegitan seperti ini di stimulir oleh dorongan dari dalam diri anak oleh impuls intern.Kegiatan bermain pada anak itu lebih tepat jika disebutkan sebagai usaha mencoba-coba dan melatih diri.

Sekalipun kita menyangka anak itu cuma bermain dengan rasa acuh tak acuh saja, namun pada hakikatnya kegiatan tadi disertai intensitas kesadaran, minat penuh, dan usaha yang keras.Gerak-gerak permainan anak itu disebabkan oleh kelebihan tenaga yang terdapat pada dirinya, dan dikeudian hari digerakkan oleh dorongan belajar guna melatih semua fungsi jasmani dan rohani (Kartono, 1995:116).

Walaupun permainan itu tampaknya tidak bertujuan, akan tetapi anak memegang peranan yang sangat penting dalam latihan pendahuluan, terutama untuk mengendalikan fungsi-fungsi jasmani dan rohani, yang dikemudian harinya akan mengarah pada kegitan intensional yang bertujuan sebagai kerja. Dengan begini anak akan terampil menggunakan semua kemapuan jasmani dan rohani untuk melakukan tugas-tugas hidupnya kelak. Dengan jalan beramain ini, anak melakukan experimentexperiment tertentu dan berexplorasi sambil menggiatkan usaha belajar dan melaksanakan tugas-tugas perkembangan. Semua pengalamannya dalam media bermain akan memberikan dasar dan media yang kokoh dalam pencapaian macam-macam keterampilan yang sangat diperlukan bagi pemecahan kesulitan hidup dikemudian harinya. Permainan yang 
mempunyai arti luas dan nilai bagi anak sebagaimana yang telah dijelaskan diatas bisa kita lihat seperti dibawah ini:

1. Permainan merupakan sarana penting untuk mensosialisakan anak.Yaitu sarana untuk mengintrodusir anak menjadi menghargai masyarakat manusia.Dalam masa permainan itu timbullah rasa kerukunan yang sangat besar artinya sebagai pembentukan social sebagai manusia budaya.

2. Dengan permainan dan situasi bermain anak bisa mengetes dan mengukur kemampuan serta potensi diri.Anak belajar menguasai bermaca-macam benda, juga belajar memahami sifat-sifat benda dan peristiwa yang belangsung dalam lingkungannya.

3. Dalam situasi bermain anak bisa menampilkan fantasi, bakat-bakat dan kecenderungannya.Anak laki-laki bermain dengan mobil-mobilannya, dan anak perempuan bermain dengan bonekanya. Jika kita memberikan kertas dan gunting pada beberapa anak, maka setiap anak akan membuat hasil yang berbeda-beda sesuai dengan bakat dan kemampuannya.

4. Ditengah permainan itu setiap anak menghayati macam-macam emosi.Dia merasakan kegairahan dan kegembiraan, dan tidak secara khusus mengharapkan prestasi-prestasi. Dengan demikian permainan mempunyai nilai yang sama besarnya dengan nilai seni bagi orang dewasa.

5. Permainan itu menjadi alat pendidikan, karena permainan kita membuat rasa puas, gembira dan bahagia pada diri anak.

6. Permainan memberikan kesempatan pra latihan untuk mengenal aturan-aturan permainan, mematuhi norma-norma dan laranganlarangan, dan bertindak secara jujur serta loyal.Semua ini untuk persiapan bagi penghayatan yang baik dalam pertarungan hidup dikemudian hari.

7. Dalam bermain, anak menggunakn semua fungsi kejiwaan dan fungsi jasmaniah dengan suasa hati kesungguhan. Hal ini pentingguna memupuk sikap serius dan bersungguh-sungguh pada usia dewasa untuk mengatasi setiap kesulitan hidup yang dihadapinya (Kartono, 1995).

Dalam hal ini bentuk permainan dapat kita bagi menjadi 3 kategori yaitu permainan yang terdapat gerakan, memberi bentuk dan ilusi, yaitu:

a. Permainan gerakan, mula-mula bayi bermain sendirian, untuk melatih gerakan badan adan anggota tubuh dengan menggunakan bermacamacam manipulasi. Pada usia sekitar 3-4 tahun timbul kebutuhan untuk bermain-main dengan kawan-kawannya, selanjutnya anak melakukan kerjasama dengan teman sepermainannya dengan beraneka ragam gerak dan olah tubuhnya.

b. Permainan memberi bentuk, alat permainan dan bahan permainan yang paling baik adalah materi tanpa bentuk, seperti lilin, kertas, air, tanah liat, balok-balok kayu, pasir dan lain-lain. Dan tepat yang paling ideal adalah pantai atau pegunungan yang tenang dan teduh.

c. Permainan ilusi, pada permainan ini unsur fantasi yang paling memegang peranan penting.Misalnya sebuah sapu menjadi kuda 
tungganggan, kursi menjadi sebuah mobil, termasuk permainan menirukan juga dikategorikan dalam permainan ini.Seperti bermain ibuibuan, dokter-dokteran, atau tentara, dan lain sebagainya.

d. Dalam hal ini, permainan tersebut anak dengan semangat memasuki dunia ilusi yang dijadikan dunia sungguh-sungguh oleh fantasi anak.

Kemudian langkah-langkah utama yang dapat diambil oleh setiap pendidik dan orang tua dalam aktifitas bermain adalah sebagai berikut:

1) Jangan menganggu anak-anak yang sedang asyik bermain dengan permainannya.Terpaksa harus mengalihkan permainannya yang mungkin sedikit berbahaya, maka usiklah sedikit demi sedikit dengan ungkapan-ungkapan yang membangun dan menyenangkan.

2) Kemudian yang penting juga adalah bukan jenis dan mahalnya permainan akan tetapi memberikan kesempatan bermain yang cukup kepada anak untuk bergembira dan melatih diri anak.

3) Memberikan ruang bermain yang cukup luas, khususnya untuk anakanak kota dimana ruang bermain hampir tidak ada dan anak dihadapkan pada banyak bahaya dijalan-jalan raya.

4) Dengan memberikan kesempatan bermain yang kreatif, secara tidak langsung kita telah mencegah dorongan untuk berbuat yang merusak, jadi timbulnya anak-anak yang nakal.

5) Bentuk permainan yang paling ideal terutama bagi anak-anak yang masih sangat muda adalah material yang mudah dibentuk seperti lilin, balok kayu, kertas, dan lain-lain.

6) Dengan bertambahnya usia anak hendaknya disamping unsur suasana permainan yang menyenangkan, perlu pula ditambahkan dimensi kerja, dan kesibukan yang bermanfaat, dan anak mulai merasakan kebahagiaan melalui prestasi sendiri, sehingga anak bisa menghayati rasa kebanggaan oleh hasil karyanya sendiri (Kartono, 1995).

\section{KURIKULUM PENDIDIKAN ANAK USIA DINI}

Pendidikan anak usia dini telah menjadi perbincangan yang tidak pernah ada hentinya, dan selalu dikaji. Pada akhirnya pemerintah mendirikan lembag-lembaga khusus yang menaungi pendidikan anak-anak usia dini. Menurut ketua yayasan Taman Pendidikan Anak Sunan Ampel Kediri, Anis Humaidi, mengatakan "bahwa yang termasuk melatarbelakangi diadakan pendidikan anak usia dini atau PAUD karena zaman dewasa ini banyak moral bangsa Indonesia yang rusak dan semua ini diawali dengan pendidikan sesorang sejak dini, kemudian juga dengan diadakan pendidikan ini akan mencetak manusia-manusia yang cerdas dan mempunyai skill yang bagus dalam kehidupannya kemudian, yang dimulai dari pengoptimalan pendidikan sejak dini". Berlatarbelakang dari hal ini juga, pemerintah tergugah, khususnya di Departemen Pendidikan Nasional untuk membentuk sebuah direktorat baru yang bernama PADU. Yaitu direktorat yang berada dibawah Direktorat Jenderal Pendidikan Luar Sekolah dan Pemuda, hal ini diharapkan dapat mendorong dan memfasilitasi masyarakat dibidang layanan pendidikan anak usia dini (Depdiknas, 2002:1).

Dasar pendidikan anak usia dini ini adalah Undang Undang No. 20 tahun 2003 pasal 1 butir 14, berisi "pendidikan anak usia dini adalah suatu 
upaya pembinaan yang ditunjukkan pada anak sejak lahir sampai dengan usia 6 tahun yang dilakukan melalui pemberian rangsangan pendidikan untuk membantu pertumbuhan dan perkembangan jasmani dan rohani agar anak memiliki kesiapan dalam hal memasuki pendidikan lebih lanjut" (Sisdiknas No. 20 Tahun 2003).

Kemudian kurikulum ada pada pasal 1 butir 19 yang bunyinya adalah "kurikulum adalah seperangkat rencana dan pengaturan mengenai tujuan, isi, dan bahan pelajaran serta cara yang digunakan sebagai pedoman penyelenggaraan kegiatan pembelajaran untuk mencapai tujuan pendidikan tertentu" (Sisdiknas, No,. 20, Tahun 2003).

Kemudian dasar hukum secara umum tentang pendidikan anak usia dini adalah sebagai berikut (Depdiknas 2006:2):

a) Undang-Undang Dasar 1945

b) Undang-Undang No. 20 tahun 2003 tentang Sistem Pendidikan Nasional

c) Undang-Undang No.23 tahun 2002 tentang Perlindungan Anak

d) Undang-Undang No. 4 tahun 1974 tentang Kesejahteraan Anak

e) Peraturan Pemerintah No. 19 tahun 2005 tentang Standar Nasional Pendidikan

f) Peraturan Presiden RI No. 7 tahun 2005 tentang Rencana Pembnagunan Jangka Menengah Nasional tahun 2004-2009

g) Keputusan Mentri Pendidikan Nasional No. 13 tahun 2005 tentang Organisasi dan Tata Kerja Direktorat Jenderal Pendidikan Luar Sekolah, Departemen Pendidikan Nasional

h) Rencana Strategi Departemen pendidikan Nasional tahun 2005-2009

Dalam pendidikan anak usia dini terdapat menu pembelajaran, yaitu sebagai berikut:

\section{Arah kegiatan pendidikan}

Dalam menyusun rencana kegiatan pendidikan diarahkan pada tiga peran pendidikan bagi anak dini usia, yaitu: (1) Pendidikan sebagai proses belajar dalam diri anak, (2) Pendidikan sebagai proses sosialisasi, dan (3) Pendidikan sebagai proses pembentukan kerjasama peran. Selain itu, kegiatan pendidikan anak usia dini hendaknya memperhatikan Sembilan kemampuan belajar anak yang meliputi: (a) Kecerdasan linguistic (linguistic intelligence), (b) Kecerdasan logika ateatik (logica-mathematical intelligence), (c) Kecerdasan visual-spasial (visual-spatial intelligence), (d) Kecerdasan musical (musical intelligence), (e) Kecerdasan kinestetik (kinesthetic intelligence), (f) Kecerdasan naturalis (naturalist intelligence), (g) Kecerdasan interpersonal (interpersonal intelligence), (h) Kecerdasan intrapersonal (intrapersonal intelligence), dan (i)Kecerdasan spiritual (spiritual intelligence).

Aspek pengembangan diarahkan pada: (1) Pengembangan moral dan nilai-nilai agama, (2) Pengembangan fisik, (3) Pengembangan bahasa, (4) Pengembangan kognitif, (5) Pengembangan social emosional, dan (6) Pengembangan seni. Adapun struktur pembelajarannya, dikelompokkan 
menurut: Kelompok usia, Aspek pengembangan, Kompetensi dan hasil belajar, dan Indikator kemampuan.

\section{Usia 3-4 Tahun}

1. Pengembangan moral dan nilai-nilai agama

Kompetensi dan hasil belajar yang ingin dicapai adalah kemampuan melakukan ibadah, mengenal dan percaya akan ciptaan Tuhan dan mencintai sesama.

2. Pengembangan fisik

Kompetensi dan hasil belajar yang ingin dicapai adalah kemampuan mengelola dan ketrampilan tubuh termasuk gerakan-gerakan yang mengontrol gerakan tubuh, gerakan halus dan gerakan kasar, serta menerima rangsangan sensorik (panca indra).

3. Pengembangan bahasa

Kompetensi dan hasil belajar yang ingin dicapai adalah kemampuan menggunakan bahasa untuk pemahaman bahasa pasif dan dapat berkomunikasi secara efektif yang bermanfaat untuk berfikir dan belajar.

4. Pengembangan kognitif

Kompetensi dan hasil belajar yang ingin dicapai adalah kemampuan berfikir logis, kritis, memberikan alasan, memecahkan masalah dan menemukan hubungan sebab akibat.

5. Pengembangan social emosional

Kompetensi dan hasil belajar yang ingin dicapai adalah kemampuan mengenal lingkungan alam, lingkungan social. Peranan masyrakat dan menghargai keragaman social dan budaya, serta mampu mengembangkan konsep diri, sikap positif terhadap belajar, control diri dan rasa memiliki.

6. Pengembangan seni

Kompetensi dan hasil belajar yang ingin dicapai adalah kemampuan terhadap kepekaan irama, nada, bunyi, tepuk tangan, serta menghadapi hasil karya yang kreatif.

\section{Usia 4-5 Tahun}

1. Pengembangan moral dan nilai-nilai agama

Kompetensi dan hasil belajar yang ingin dicapai adalah kemampuan melakukan ibadah, mengenal dan percaya akan ciptaan Tuhan dan mencintai sesame.

2. Pengembangan fisik

Kompetensi dan hasil belajar yang ingin dicapai adalah kemampuan mengelola dan ketrampilan tubuh termasuk gerakan-gerakan yang mengontrol gerakan tubuh, gerakan halus, serta meneria rangsangan sensorik (panca indra).

3. Pengembangan bahasa 
Kompetensi dan hasil belajar yang ingin dicapai adalah kemampuanmenggunakan bahasa untuk pemahaman bahasa pasif dan dapat berkomunikasi secara efektif yang bermanfaat untuk berfikir dan belajar.

4. Pengembangan kognitif

Kompetensi dan hasil belajar yang ingin dicapai adalah kemampuanberfikir logis, kritis, memberikan alasan, memecahkan masalah dan menemukan hubungan sebab akibat.

5. Pengembangan social emosional

Kompetensi dan hasil belajar yang ingin dicapai adalah kemampuanmengenal lingkungan alam, lingkungan social. Peranan masyrakat dan menghargai keragaman social dan budaya, serta mampu mengembangkan konsep diri, sikap positif terhadap belajar, kontrol diri dan rasa memiliki.

6. Pengembangan seni

Kompetensi dan hasil belajar yang ingin dicapai adalah kemampuanterhadap kepekaan irama, nada, bunyi, tepuk tangan, serta menghadapi hasil karya yang kreatif.

\section{Usia 5-6 tahun}

1. Pengembangan moral dan nialai-nilai agama

Kompetensi dan hasil belajar yang ingin dicapai adalah kemampuan melakukan ibadah, mengenal dan percaya akan ciptaan Tuhan dan mencintai sesame.

2. Pengembangan fisik

Kompetensi dan hasil belajar yang ingin dicapai adalah kemampuan mengelola dan ketrampilan tubuh termasuk gerakan-gerakan yang mengontrol gerakan tubuh, gerakan halus dan gerakan kasar, serta menerima rangsangan sensorik (panca indra).

3. Pengembangan bahasa

Kompetensi hasil belajar yang ingin dicapai adalah kemampuan mengucapkan bahasa untuk pemahaman bahasa pasif dan dapat berkomunikasi secara efektif yang bermanfaat untuk berfikir dan belajar.

4. Pengembangan kognitif

Kompetensi dan hasil belajar yang ingin dicapai adalah kemampuan berfikir logis, kritis, memberikan alas an, memecahkan masalah, dan menemukan hubungan sebab akibat.

5. Pengembangan sosial emosional

Kompetensi dan hasil belajar yang ingin dicapai adalah kemampuan mengenal lingkungan alam, lingkungan sosial, peranan masyarakat, dan menghargai keberagaman sosial dan budaya, serta mampu mengembangkan konsep diri, sikap positif terhadap belajar, kontrol diri, dan rasa memiliki.

6. Pengembangan seni 
Kompetensi dan hasil belajar yang ingin dicapai adalah kemampuan terhadap kepekaan irama, nada, bunyi, tepuk tangan serta menghargai hasil karya yang kreatif.

Sebagai tambahan, terdapat pendapat yang menjelaskan bahwa anak juga baik untuk diperkenalkan akan perkembangan teknologi. Seperti penggunaan multimedia pada anak-anak yang diaplikasikan pada computer memberikan pengaruh positif. Seperti yang telah dikemukakan oleh Nur Alny Faidana dalam bulletin PAUD bulan April 2006, menurut penelitian yang dilakukan oleh Li dan Atkins (2004) menyimpulkan bahwa pengalaman dalam computer secara lebih awal sebelum usia prasekolah berhubungan dengan kemampuan membentuk konsep dan kognisi serta kesiapan bersekolah pada anak-anak. Dengan demikian ternyata multimedia memili serangkaian keuntungan bagi optimalisasi perkembangan anak dalam berbagai aspeknya.Namun para orangtua dan pendidik perlu mewaspadai ancaman yang dapat ditimbulkan dari penggunaan multimedia bagi anak.

\section{PENUTUP}

Pendidikan itu mulai anak sejak usia dini, bahkan pendidikan anak usia taman kanak-kanak bisa dikatakan terlambat. Hasil penelitian neurologi Bloom menegaskan usia 4 tahun pertama separuh kecerdasan manusia sudah terbentuk. Pada usia tersebut otak anak tidak akan berkembang secara optimal. Sampai usia 8 tahun $80 \%$ kapasitas kecerdasan anak hanya bertambah sekitar $30 \%$ setelah usia 4 tahun hingga mencapai usia 8 tahun. Baru kemudian kapasitas kecerdasan anak bisa mencapai $100 \%$ setelah berusia sekitar 18 tahun.

Ketika anak sudah bisa mendengarkan sesuatu, anak sudah bisa mendapatkan pendidikan. Anak usia dini yaitu ketika anak sudah mulai berbicara dan menirukan hal-hal yang ada disekitarnya. Anak wajib kita bimbing dengan pendidkan yang patut dan sesuai dengan usinya. Sangat berbahaya ketika anak disuguhi media yang tidak sepatutnya, misalnya anak dieksploitasi mengikuti gaya dan mode orang dewasa, menyanyi lagu-lagu dewasa, mengikuti adegan film remaja, dan bahkan baju yang dikenakan oleh orang dewasa. Hal ini sangat buruk dampaknya bagi perkembangan emosi, psikologi anak dan berdampak besar ketika memasuki usia remaja. Kenyataannya, implementasi peraturan dan hukum untuk anak masih sangat sedikit, terutama karena kurangnya kesadaran orang tua dalam mendidik anak yang sesuai dengan usia dan peraturan yang berlaku.

\section{DAFTAR PUSTAKA}

Departemen Pendidikan Nasional, Pedoman Penerapan Pendekatan Beyond Centers and Circle Time (BCCT) Pendekatan sentra dan Saat Lingkaran dalam Pendidikan Anak Usia Dini Jakarta: Departemen Pendidikan Nasional, 2006

Direktorat Anak Usia Dini, Acuan Menu Pada Kelompok Bermain Jakarta:

Departemen Pendidikan Nasional, 2002

http://www.nickir.co/parenting/activityfinder/game/index.html

Kartono Kartini, Psikologi Anak Bandung: Mandar Maju, 1995 
p-ISSN: 1979-9438, e-ISSN: 2445-2355

FKIP Universitas Islam Balitar, Blitar

Yusuf Syamsu, Psikologi Perkembangan Anak dan Remaja Bandung: PT Remaja Rosdakarya, 2005.

Undang-undang RI No. 20 Tahun 2003 SISDIKNAS Jakarta: Cemerlang, 2003 